\title{
DEVELOPMENT OF TEST INSTRUMENTS BASED COMPUTER- HIGHER ORDER THINKING (CBT-HOT) IN INTERMEDIATE READING COURSES
}

\author{
INDRAWATI PUSPARINI', IKE DIAN PUSPITA SARI² \\ Ikip Budi Utomo Malang, Indonesia' \\ Ikip Budi Utomo Malang, Indonesia ${ }^{2}$ \\ puspaindra7।@gmail.com', ikedianpuspitasari@gmail.com² \\ DOI : http://dx.doi.org/10.29300/ling.v6i1.3069
}

\begin{abstract}
This research developed product of test instruments based computer -High Order Thinking (CBT-HOT) in intermediate reading courses in Ikip Budi Utomo Malang. Test instruments based computer -High Order Thinking (CBT-HOT) in intermediate reading courses are high-level test package that are provided online by using a website as a basis for students who access it, so it is suitable to campus vision that must use ICT technology. The product consists of five test packages compiled with high-level criteria according to Taxonomy Bloom, those are package A, B, C, D and E. The design of this research adapts from the Borg and Gall model with the following steps (1) need analysis, (2) planning, (3) product development, (4) expert validation, (5) product revisions and (6) product trials. The objectives of this study are: (1) to produce scientific articles published in reputable national journals; (2) to produce scientific article published in international scientific journals; (3) produce CBT-HOT based test computer products that will be certified. The average value on material validation showed good results, which the average score 2,81 . The average value of media validation also shows good results, which is 2.86 . The average value in test instruments is 2.87 .
\end{abstract}

Keywords: Test instruments based computer, CBT-HOT, Intermediate Reading

\section{INTRODUCTION}

According to Taxonomy Bloom, cognitive processes are divided into lower order thinking abilities (LOT) and higher order thinking abilities (HOT). The ability that includes LOT is the ability to remember, understand, and apply, while HOT includes the ability to analyze, evaluate, and create (in Anderson \& Krathwohl, 2001: 30 ). In HOTS, besides containing high-level thinking ability, it also contains creative thinking. The importance of high-level thinking ability was expressed by Fensham (2012) in order to compete in the world of work and personal life, students must have the ability to think critically, creatively and the ability to solve problems. HOTS based on Bloom's Taxonomy is included in the five highest levels, namely analysis (C4), evaluation (C5), synthesis (C6), imagination (C7), and creation (C8). Bloom's revised taxonomy is divided into two thought processes, namely be skills 
analysis and synthesis (C4), evaluating (C5), and creating or creativity (C6) (Krathworl and Anderson, 2001).

According to Barnett \& Francis (2012: 209), that higher-order thinking questions can encourage students to think deeply about the subject matter, so it can be said that tests of higherorder thinking skills can provide stimulation to students to develop higher-order thinking skills.

But in fact, the application of HOTS learning is not an easy thing to do by the teacher. The teacher must really master the material and learning strategies. The teacher is also faced the student environment challenges. Learning will be meaningful if students are invited to think at a high level. The success of mastering a concept will be obtained when students are able to think at a high level, where students can not only remember and understand a concept, but also students can analyze, synthesize, evaluate, and create a concept well, the concept that has been understood can be embedded in memory students for a long time, so it is very important for students to have higher-order thinking skills or HOTS (Laily, 2013).

Based on observations in learning intermediate reading course in Ikip Budi Utomo Malang so far, the reading tests have been used not oriented towards measuring students' high-level thinking skills, but they still focus on low-level learning outcomes. The test questions presented are only based on what is in the contents of the reading while learning takes place, so what happens is students answer quickly all questions because the answers are already in the reading text. There is no challenge to think at a high level, because students are less motivated in attending learning, and they experience boredom. This is indicated by the students who are still having difficulty analyzing existing information. They tend to accept what information is obtained, passive in asking questions or answering questions from problems raised by teachers, and passive in terms of presenting ideas or problem solving ideas.

Based on these problems, it is necessary to have a high-level thinking test to improve the ability of high order thinking and student motivation. In addition, along with the development of technology and information, currently computer-based tests that can be done using a website application system, so that lecturers should no longer use conventional tests (paper tests). This conventional test format has several problems, one of which is that the lecturer is sometimes less thorough in the assessment process so that the assessment error occurs. Test instruments that are still conventional in nature are certainly less effective, efficient, unattractive and not up to date. The test instruments based computer -High Order Thinking (CBT-HOT) in intermediate reading courses is a very promising tool for educational measurement. Therefore, lecturers must be able to take advantage of current technological developments to conduct computer-based tests. 
Based on the problems outlined above, one of the efforts that can be done to overcome these problems is to develop a high-level thinking test package that is packaged by using a computer as a tool for storing, processing and processing tests that have been prepared for use in assessing students. Output targets of this research are expected to be distributed through national scientific publications in ISSN journals and at international scientific journal, and the product can be recognized with certified

The product to be developed in this research is test instruments CBT-HOT based computer test which contains test instruments for Intermediate Reading subject learning materials. The specifications are as follows: (1) this test instrument was developed on the internet using google form to upload material. The development can be done using google form application systems (2) Google form is embedded in blog onlineclass_me.blospot.com (3) the material and tests posted are adjusted to the needs of students as stated in the syllabus of Intermediate reading courses (4) Online learning using chat through google classroom, so students have the opportunity to ask more about the material and test.

\section{Test}

According to Brown (2003), a test, in simple terms, is a method of measuring a person ability, knowledge, or performance in a given domain. A test is first a method. It is an instrument-a set of techniques, procedures, or items that requires performance on the part ofthe test-taker. To qualify as a test, the method must be explicit and structured: multiple-choice questions with prescribed correct answers; a writing prompt with ;t scoring rubric; an oral interview based on a que; tion script and a checklist of expected responses to be filled in by the administrator.

Second, a test must measure. Some tests measure general ability, while others focus on very specific competencies or objectives. A multi-skill proficiency test determines a general ability level; a quiz on recognizing correct use of defmite articles measures specific knowledge.

Next, a test measures an individual's ability, knowledge, or performance. Testes need to understand who the test-takers are. What is their previous experience and background? Is the test appropriately matched to their abilities? How should test . takers interpret their scores? A test measures performance, but the results imply the test-taker's ability, or, to use a concept common in the field of linguistics competence.

Finally, a test measures a given domain. In the case of a proficiency test, even though the actual performance on the test involves only a sampling of skills, that domain is overall proficiency in a language-general competence in all skills of a language. Other tests may have more specific criteria. 
According to Brown (2003) in his book Language Assessment, he classified the characteristic of Good Test be 3 parts: 1 . Validity, 2. Reliability, and 3. Practicality. Practicality refers to the usability of a test. It involves three aspects: economical in time and finance, easy to administer and score, and easy to interpret.

\section{Reading}

M.R. Patel and Pravin M. Jain (2008: 114-116) : The first stage, which is the 'introduction' stage. At this stage students are quite familiar with the parts related to phonological items. For example, students recognize / understand language verbally in written form. The difficulty at this stage depends on the difference between mother tongue students with English and between the spelling rules of the two languages. The second stage, which is the 'arrangement' stage. At this stage students understand the syntactic relationship of reading items and understand the structural meaning of these syntactic items. The third stage, which is the 'interpretation' stage. This stage is the highest stage in the reading process. Students understand the importance of a word, phrase or sentence in all unnecessary contexts. For example, students understand the use of serious words and funny words. He can distinguish statement of fact and statement of opinion. It is at this stage that a person actually reads to get information or reads to simply amuse himself.

\section{Factors Influencing Reading Comprehension}

The success of failure in understanding written material depends on many factors. These factors can be classified into three categories: reader, textual and instructional.

First, what is included in the reader category is psychological factors such as attitudes, interests, motivation, and habits. These factors are interrelated in the sense that the reader's personal attitude towards a particular reading topic determines his interest in reading it. Negative attitudes generate bad interests and positive attitudes generate good interests. Then, when he is interested in reading, he will be motivated to read and finally he will have good reading habits.

Besides psychological conditions in the reader, cognitive abilities and intellectual skills generally also affect reading comprehension. They include the ability to decode, to recognize the sequence of inductive ideas that lead to a conclusion, to deductively apply a principle to a new situation; and to recognize cause-effect, comparison, contrast, and other idea relationships.

The last, memory plays an important role in reading comprehension. The reader must remember what he read and his own experience and other relevant readings. Overall, these factors produce understanding, broadening the meaning of the reader being able to take what 
he reads (Olson and Diller, 1982; Turner in Alexander, 1988). Reader linguistic knowledge, such as vocabulary knowledge and syntactic structure, also influences reading comprehension. Therefore, being unfamiliar with difficult words and structures presented by the text writer cannot hinder the reader's understanding. In addition, the reader's unfamiliarity with the concepts discussed in the text also results in poor understanding (Olson and Dilner, 1982; Nuttal, 1982; Harris and Sipay, 1980).

\section{High Order Thinking Skills}

Higher Order of Thinking Skills (HOTS) is the ability to think critically, logically, reflective, metacognitive, and creative thinking which is the ability to think at a higher level. According to Heong, et al (2011) higher order thinking is using the thinking widely to find new challenges. Higher order thinking demands someone to apply new information or knowledge that he has got and manipulates the information to reach the possibility of answer in the new situation. In HOTS students use thinking widely to find new challenges. Higher-order thinking requires a person to apply the information or new knowledge he gets and manipulate information to reach possible answers in new situations.

Several studies have written the definition of HOTS that HOTS is an internal process that occurs within a person which is characterized by several characteristics as follows: (1) Involving more than one correct answer; (2) Talk about level of understanding; (3) Characterized by complex tasks; and (4) Free content and at the same time content-related, Astutik, (tth, p. 343); Zaini (2015).

In HOTS, besides containing high-level thinking ability, it also contains creative thinking. The importance of high-level thinking ability was expressed by Fensham (2012) in order to compete in the world of work and personal life, students must have the ability to think critically, creatively and the ability to solve problems. HOTS based on Bloom's Taxonomy is included in the five highest levels, namely analysis (C4), evaluation (C5), synthesis (C6), imagination (C7), and creation (C8). Bloom's revised taxonomy is divided into two thought processes, namely higher order thinking skills or often referred to as Higher Order Thinking Skills (HOTS), and lower order thinking skills Lower Order Thinking Skills (LOTS). Lowlevel thinking skills involve the ability to remember $(\mathrm{C} 1)$, understand $(\mathrm{C} 2)$ and apply $(\mathrm{C} 3)$ while high-level thinking skills involve analysis and synthesis (C4), evaluating (C5), and creating or creativity (C6) (Krathworl and Anderson, 2001).

Each lecturer should be creative in developing HOTS questions in accordance with the syllabus. Lecturers' insights on global issues, skills to choose stimulus questions, as well as the ability to choose competencies tested, are important aspects that must be considered, in order 

to produce points quality items. Below is the Bloom's taxonomic cone which is classified based on HOT to LOTS

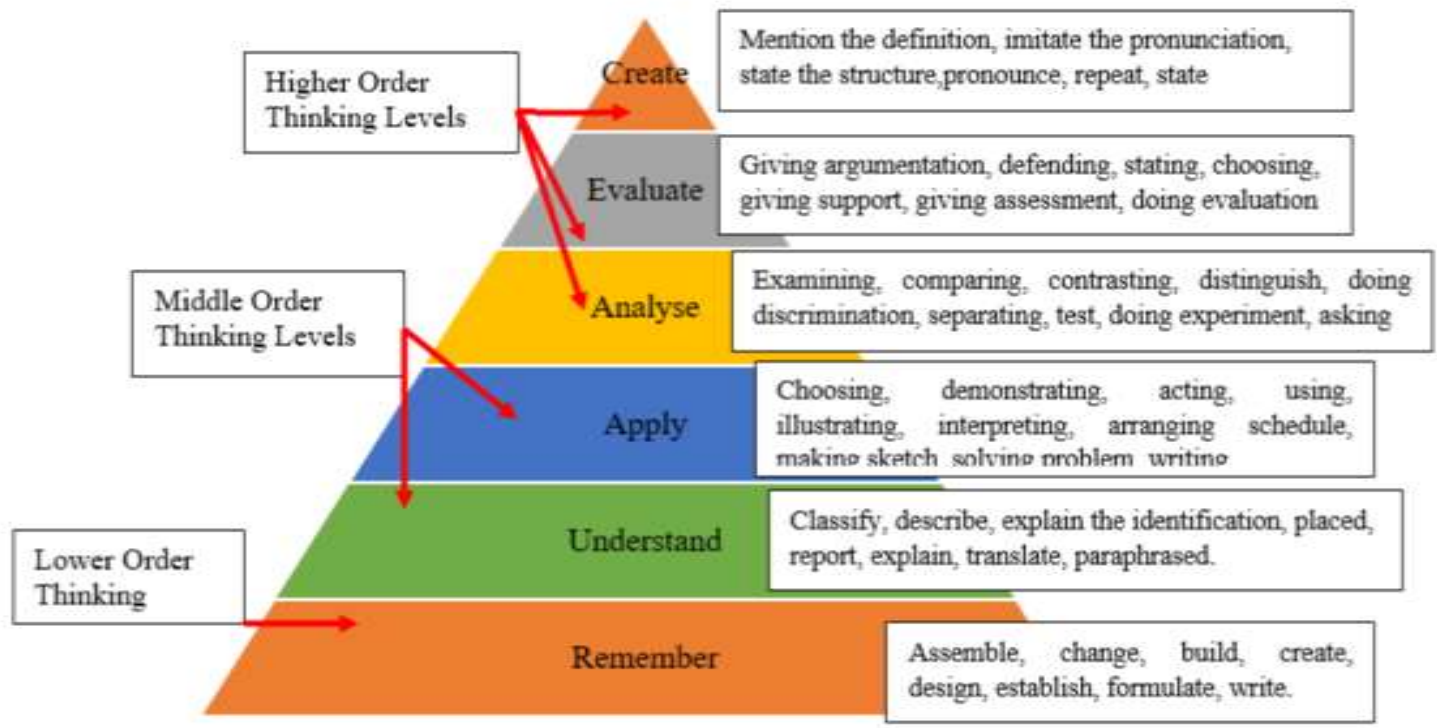

Figure 1. Taksonomi Bloom HOTS - LOTS (Anderson, L.W., and Krathwohl, D.R., 2001)

In writing HOTS questions, it takes mastery of teaching materials, skills in writing questions (problem construction), and teacher creativity in choosing stimulus questions in accordance with the situation and conditions of the area around it. This feature is a chart of steps for compiling HOTS questions.

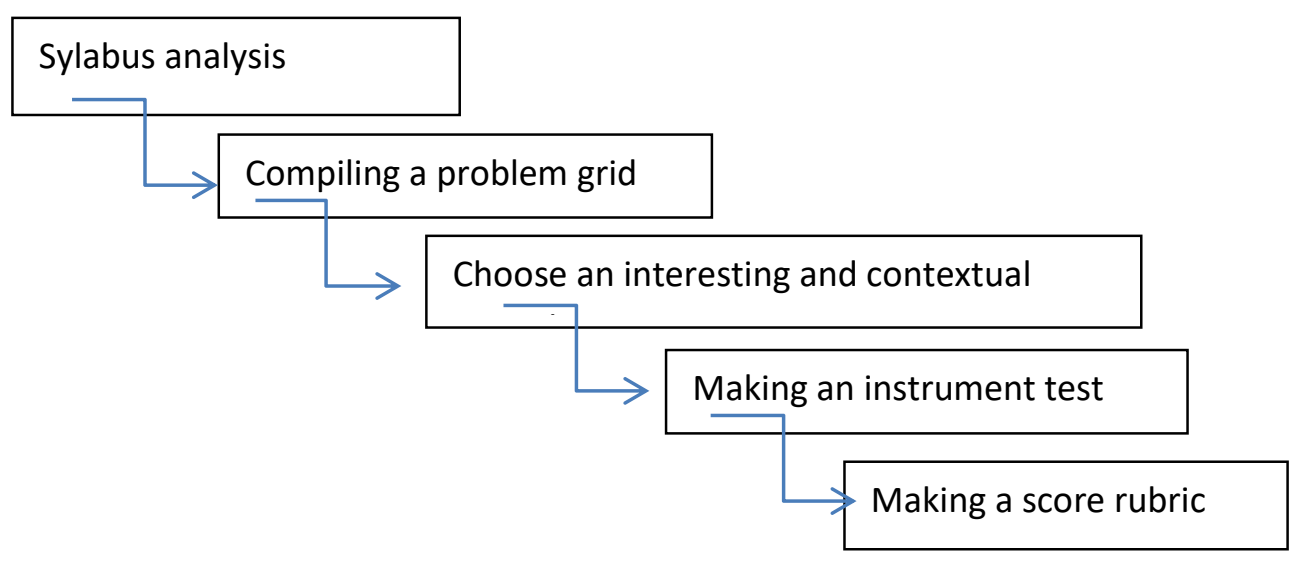

Figure 2 . Steps for preparing the HOT questions

\section{METHOD}

This type of research is development research. The development method used is Research and development, a method used to produce certain products and test the effectiveness of these products. The design of this test instruments includes stages one through 
seven adapted from Gall, Gall and walter (2005) with the following steps (1) needs analysis, (2) planning, (3) product development, (4) expert validation, (5) product revision and (6) test try the product

Validation of test instrument based on computer test includes assessment from education experts which has been teaching structure more than 10 years. The subjects of the trial were the third semester students in Intermediate reading in the English language department, 90 students of IKIP Budi Utomo Malang.

The instruments of data collection are questionnaires and interview. Data are obtained from test instrument, teaching learning process questionnaires by observers and teaching learning process questionnaires when using online test. Data obtained from assessments will be analyzed by the average analysis technique. The average value obtained will be determined the level feasibility of the test instruments based on computer test. Determination of the average value analysis technique based on Arikunto (2010: 286) which states that to find out the final grade rating for each item in the assessment questionnaire, the number of values obtained is divided by the number of respondents who answered the assessment questionnaire. Determination of conclusions that have been achieved from limited trials in this study using a rating scale of 1 to 3, where 1 as the lowest score and 3 as the highest score. Determination of range can be known through the highest value minus the lowest value divided by the number of classes. Based on the determination of the range obtained a range of 0.67 was adapted from (Sudjana, 2005: 47).

\begin{tabular}{ccc} 
& Table 1. Validation Criteria & \\
Average & Score Description & Category \\
\hline $2.36-3.00$ & Good & Worth \\
$1.68-2.35$ & Fairly & Good Enough \\
$1.00-1.67$ & Not worth & Not Good \\
\hline
\end{tabular}

\section{FINDING AND DISCUSSION}

The initial observation that the researchers did at IKIP Budi Utomo Malang on April 2, 2020 with questionnaires. Questionnaire regarding the assesment test related to CBT-HOT, online based on computer, campus wifi facilities, classroom learning support facilities, implementation of intermediate reading online tests in class, students' interests and abilities in understanding intermediate reading materials.

Based on the questionnaire in getting $100 \%$ of students answering, students answering that they never used online test almoust 90,05\% and answering the reading test using High Order Thinking skill $89,03 \%$, wifi facilities can be reached throughout the school area $80.60 \%$, and $55.19 \%$ of students state that each student has the opportunity to use a computer 

that is in campuss. The implementation of intermediate reading in the classroom amounted to $59.06 \%$, students stated that teachers explained the material more often with lectures and this data was strengthened by the answers of students as much as $60.06 \%$ that they preferred to discuss because they could freely express their opinions to friends. In the questionnaire regarding the ability to think critically, students stated that as many as $40.71 \%$ had not been able to identify and explain intermediate reading concepts learned systematically, accurately and deeply. This is also supported by students preferring to listen to the teacher's explanation rather than having to identify the problem independently.

Based on the results of observations at IKIP BUDI UTOMO Malang, researchers conducted a plan for making test instruments CBT-HOT based on computer test. The researcher and the class teacher determine the material, syllabus and plan for implementing the learning. The implementation of test is done five times online meetings, because the test contains five test package.

The development of this hybrid learning based module, the researcher prepared a link to upload the test with the address onlineclass_me.blogspot.com. Online learning uses chat through a google classroom so students have the opportunity to ask further questions about the material. The test instruments developed have interesting images and colors so that students are more familiar with the material being studied.

Validation is carried out by a team of experts. Those are one of lecturer of Ikip Budi Utomo Malang as a validator of media, and another as a validator of material who has been teaching reading more than 10 years, and one of ITC Expert, as a validator of Information Technology.The average value on material validation showed good results, which the average score 2,81 . The average value of media validation also shows good results, which is 2.86 . The average value in online media is 2.87. Data of material validation results can be seen in Table 2. Data from the media validation can be seen in Table 3, and the results of online test instruments validation can be seen in Table 4 .

Table 2. Results of the material validation

\begin{tabular}{lccc}
\hline \multicolumn{1}{c}{ Criteria assesed } & Validator 1 & Validator 2 & qualification \\
\hline The materials are complete. & 3 & 3 & good \\
The materials are clear & 2,75 & 2,75 & good \\
$\begin{array}{l}\text { The language is clear } \\
\text { The pictures explaining } \\
\text { concepts are clear. }\end{array}$ & 2,8 & 2,8 & good \\
$\begin{array}{l}\text { The instructions are clear } \\
\text { The examples used to explain the }\end{array}$ & 2,85 & 2,85 & good \\
concepts are clear & 3 & 3 & good \\
\hline Average score & 2,5 & 2,5 & good \\
\hline
\end{tabular}


Table 3. Results of online media validation

\begin{tabular}{lccc}
\hline \multicolumn{1}{c}{ Criteria assesed } & Validator 1 & Validator 2 & Qulification \\
\hline Selection of media & 3 & 3 & Good \\
Performance & 2,75 & 2,75 & Good \\
Tecnology & 2,9 & 2,8 & Good \\
\hline Average score & 2,88 & 2,85 & Good \\
\hline
\end{tabular}

Tabel 4. Result of instrument test CBT-HOT

\begin{tabular}{llll}
\hline \multicolumn{1}{c}{ Criteria assesed } & Validator 1 & Validator 2 & Qulification \\
\hline $\begin{array}{l}\text { Problem using interesting stimulus (new, } \\
\text { encouraging students to read) }\end{array}$ & 3 & Good \\
$\begin{array}{l}\text { Problem using contextual stimuli (images / } \\
\text { graphics, text, visualization in accordance with }\end{array}$ & 2,75 & 2,75 & Good \\
the real world) * & & \\
$\begin{array}{l}\text { The problem of measuring cognitive level of } \\
\text { reasoning (analyzing, evaluating, creating) is } \\
\text { characterized by one / more of the following } \\
\text { criteria: }\end{array}$ & 2,8 & good \\
$\begin{array}{l}\text { a. Transfer one concept to another } \\
\text { b. Process and apply information }\end{array}$ & & \\
$\begin{array}{l}\text { c. Look for links of different information } \\
\text { d. Use information to solve problems }\end{array}$ & & & \\
e.Analyzing ideas and information critically & & & \\
The answer is implied by the stimulus & 2,88 & 2,85 & good \\
\hline Average score & 2,88 & 2,85 & good \\
\hline
\end{tabular}

Product revision is done by looking at the responses and suggestions from the validator. Revision for the material related to CBT-HOT, the color of the map concept has been improved so that the color looks interesting. Revisions to test instruments that are used. Revisions online media, use google form that embedded to blog has been revised so that the test instruments is clearly visible.

The final product is test instruments CBT-HOT based on computer test in accordance with the responses and suggestions given from the experts, lectures and students. Products that are refined according to the needs of students to learn through google form. The enhanced package tests contains instructions for using test, objectives, analysis questions and scoring rubric . The test packages are equipped with colored images making it easier for students to understand the material.

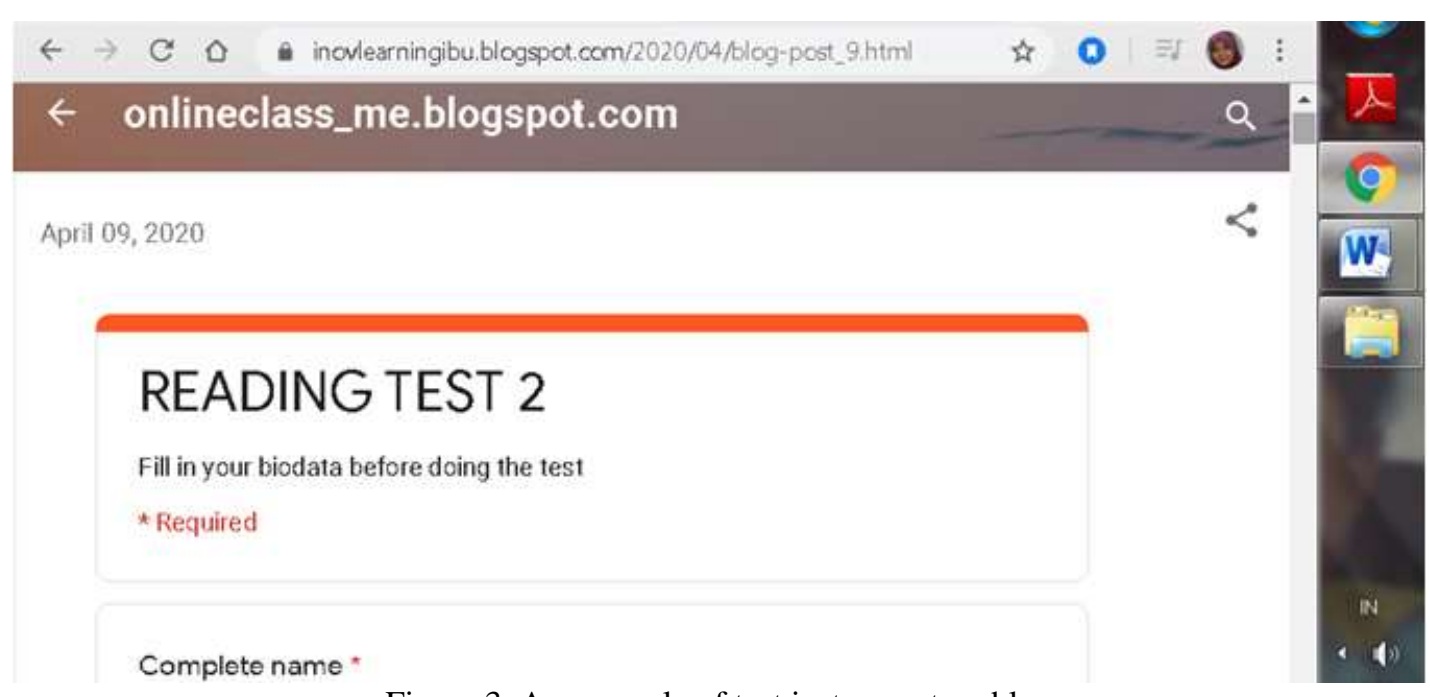

Figure 3. An example of test instrument on blog 


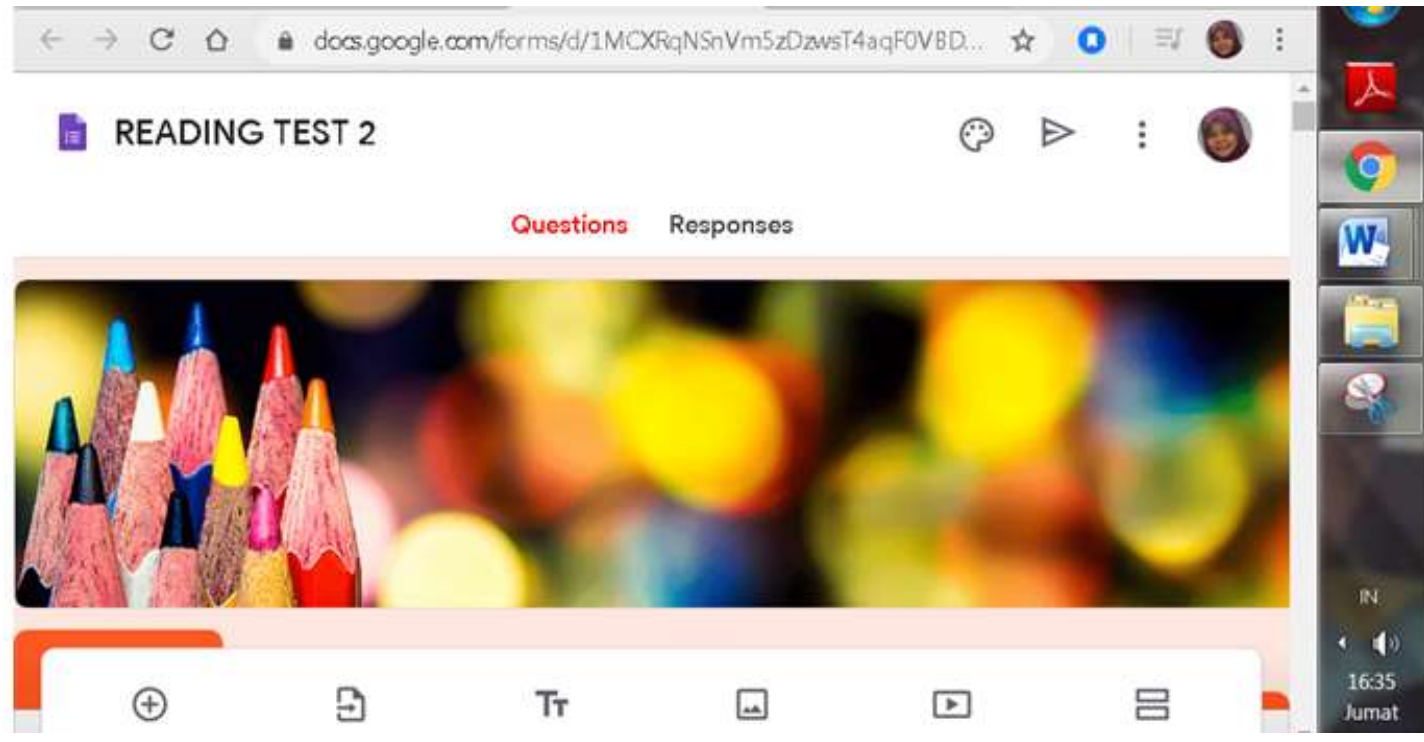

Figure 4. An example of test instrument "reading test 2 "

5. The fact that the writer of the passage thinks that we can kill dolphins more easily than they can kill us --.

means that they are better adapted to their enyironment than we are

shows that dolphins have a very sophisticated form of communication

proves that dolphins are not the most intelligent species at sea

does not mean that we are superior to them

proves that Dolphins have linguistic skills far beyond what we previously thought

Figure 5. An example of the question

\section{DISCUSSION}

Test Instruments CBT-HOT based computer at the validation stage are declared valid in terms of material, media, and also instrument tests; so this test instruments CBT_-HOT based computer can be used for learning in Intermediate Reading. Test Instruments CBT-HOT based on computer is developed according to the wishes and conditions of students. Test Instrument CBT-HOT based computer is presented more on the application of google form embeded on blog so students learn easily. The existence of test in the form of google application, students are more interested in learning compared to the test in the form of paper. Test Instruments CBT-HOT based computer can improve student learning outcomes. This is because learning through technology students can more successfully achieve learning goals than traditional learning. 
Some obstacle finding that need to be conveyed are 1). before using the test intruments test, some students have not already understand how to use the test instruments usage instructions, 2). The limitted acces support from campuss such as the provision of wi-fi facilities, computers, laptops related to product operations, 3). Some of the student have not already addressed about the technology, it need support from campuss such as providing training or workshops on website utilization in google application for student and also teachers if it necessary, 4). based on the level of feasibility obtained, the test intruments can be used as a reference for the development of other reading material, so there needs to be a study of test intruments on a broad scale. 5). there is a need for wi-fi or modem facilities have limited acces and connections at campuss, so students are bothered by a slow internet connection.

\section{CONCLUSION}

Conclusion Test Intruments CBT-HOT based on computer have been declared valid, so they can be used for student learning. Test Instruments CBT-HOT based computer can improve learning outcomes. Some of the advantages of Test Intruments CBT-HOT based on computer the use of technology, communication that is not limited to space and time and learning resources that can be accessed. The Test Intruments CBT-HOT based computer was developed to help students learn more efficiently and not just memorize a material.

Some suggestions that need to be conveyed are 1). before using the test , teachers and students should already understand how to use the test intruments in the test usage instructions, 2). policy support from campuss is needed such as the provision of wi-fi facilities, computers, laptops related to product operations, 3). need policy support from campuss such as providing training or workshops on website utilization in google application for teachers, 4). based on the level of feasibility obtained, the test instruments can be used as a reference for the development of other structure material, 5). there needs to be a study of test intrumens on a broad scale. 6). there is a need for wi-fi or modem facilities with fast connections at campuss or at home so students are not bothered by a slow internet connection so students can do online learning.

In reference to the findings, some recommendations are made for the teacher and future studies; The first recommendation is objected to classroom teachers of teaching, as they are facilitator in test intruments process. Encouraging the students to address with ICT tools sometimes can be hard efford to do. Student sometimes felt lazy to start or learn a new technology. They will encourage if the new media of teaching which is easy to take in their's hand. 
Indrawati Pusparini, Ike Dian Puspita Sari

The second recommendation goes to further studies. Relevant to the finding, suggestions for further research are made as follows: 1) the present study uses only students of Ikip Budi Utomo who learn Intermediate Reading as the target population. Further studies are suggested to be conducted to students at university who learn other subject course, 2)the present study is limited only to use test intruments in Intermediate Reading . It is suggested that future study be conducted to include the evaluation level other comprehension, such as: speaking, writing and listening

\section{REFERENCES}

Anderson, L.W., and Krathwohl, D.R. (2001). A Taxonomy of Learning, Teaching, and Assessing: A Revision of Bloom's Taxonomy of Educational Objectives. New York: Longman. P.

Anderson, L.W., dan Krathwohl, D.R. (2001). A Taxonomy for Learning, Teaching, and Assesing: A Revision of Bloom's Taxonomy of Educational Objectives. New York: Addison Wesley Longman, In.

Anderson, L. W., \& Krathwohl, D. R. (2010). Kerangka Landasan Untuk Pembelajaran, Pengajaran, dan Asesmen. Yogyakarta: Pustaka Pelajar.

Astutik, P. P. (2016). Integrasi Penguatan Pendidikan Karakter (PPK) Dan Higer Order Thinking Skills (HOTS) dalam Pembelajaran Tematik SD. Fakultas Ilmu Pendidikan Universitas Negeri Malang

Barnett, J. E., \& Francis, A. L. (2012). Using higher order thinking questions to foster critical thinking: A classroom study. Educational Psychology, 32(2), 201-211

Brown, Douglas. 2003. Language Assessment: Principles and Classroom Practice. USA: Longman.

Direktorat Pembinaan SMA Ditjen Pendidikan Dasar dan Menengah. (2017). Modul Penyusunan Soal Higher Order Thinking Skills (HOTS). Jakarta: Direktorat Pembinaan SMA Direktorat Jenderal Pendidikan Dasar Dan Menengah Departemen Pendidikan Dan Kebudayaan

Doganay, A. and Bal, A. P. (2010). The Measurement of Students' Achievement in Teaching Primary School Fifth Year Mathematics Classes. Educational Science: Theory \& Practice, 10(1), pp. 199215 .

Gall, J.P., Gall, M.D \& Walter, R.B. (2005). Applying Educational Research: A Practical Guide. London: Pearson

Heong, Y. M.,Othman, dkk. (2011). The Level of Marzano Higher Order Thinking Skills Among Technical Education Students . International Journal of Social and humanity, Vol. 1,No. 2, July 2011, 121- 125

Kemendikbud, 2017. Modul Penyusunan Higher Order Thinking Skill (HOTS). Jakarta: Direktort Jenderal Pendidikan Dasar dan Menengah Departeman Pendidikan dan Kebudayaan.

Lailly, N. R., \& Wisudawati, A. W. (2015). Analisis Soal Tipe Higher Order Thinking Skill (HOTS) dalam Soal UN Kimia SMA Rayon B Tahun 2012/2013. Jurnal Kaunia, 11(1), 27-39 
M.R. Patel and Pravin M. Jain (2008). English Language Teaching (Methods, Tools and Techniques) . Vaishali Nagar, Jaipur : Sunrise Publihers and Distributors

Olson, Joane P and Diller, Martha, H. Learning to Teach Reading at Elementary School New York : Macmillan Publishing Co, Inc

Pratiwi, U., \& Fasha, E. F. (2015). Pengembangan Instrumen Penilaian HOTS Berbasis Kurikulum 2013 Terhadap Sikap Disiplin. Jurnal Penelitian dan Pembelajaran IPA, 1(1), 123-142.

Sudjana. 2005. Metoda Statistika. Bandung: Tarsito.

Zaini, M. (2015). Hasil belajar dan keterampilan berpikir tingkat tinggi siswa SMA pada pembelajaran biologi menggunakan model pembelajaran berdasarkan masalah. Jurnal Pendidikan Biologi, 20(207) 